\title{
An Analysis of Recount Text Comprehension At the Eighth Grade of SMPN 12 Jambi City
}

\author{
Yenti* \\ State Islamic University Sulthan Thaha Saifuddin Jambi \\ *Correspondence email: yenti@uinjambi.ac.id
}

\begin{abstract}
In Junior High School, the students should have reading skill. Good achievement in reading is very important for the students. When the researcher did observation at the eighth grade students of SMPN 12 Jambi City, it was found that some of the students have difficulties in comprehending a recount text. The aim of this research is to find out students difficulties in comprehending a recount text at the eighth grade students of SMPN 12 Jambi City Academic Year 2018/2019. The researcher used qualitative method to analyze the data. There were thirty two students of the eighth year of SMPN 12 participated in this research. Observation, questionnaire and interview data were collected, analyzed and collated. The researcher found that some students had difficulty in understanding the content of the text and difficult to interpret the English language, which is almost the same answer choices that confuse students. Students simply read without understanding the text, not thorough in answering questions. The students difficult in comprehending a recount text questions. There are inability to access the content of the text.
\end{abstract}

Keywords: an analysis; recount text; reading comprehension

\section{INTRODUCTION}

According to Sisdiknas (2004) in English language is a tool to communicate orally and in writing. Understanding communication is understand to expressing information, thoughts, feeling and develops science, technology, and culture using the language. The ability to understand and produce spoken or written text that is realized in the four skills, namely listening, speaking, reading and writing. Those four skills were used to respond or create a discourse in public life. The English education aimed at developing these skills so that graduates are able to communicate or discourse.

English nowadays as one of the foremost international languages, consequently, it has huge impact in educational curriculum in many countries including Indonesia, especially in establishment of English as one of subject matter that is evaluated in national standard evaluation, better known as national examination, all education institutions such as school every year to help their students passing examination. Particularly in English subject and usually test from multiple choice.

In Junior High School, the students should have reading skill. Good achievement in reading is important for the students. The students will get information and ideas. So, it needs to use appropriate method in teaching reading, in order to produce good reading ability, so that reading as their subject should be learnt. They are not only need read the text but also to know about the genre of text.

One if the type of text is recount text. Nunan Suryana (2008) defines recount text is the text to tell what happen and to achieve the purpose is told of the text or to retell events for the purpose of informing or entertaining. In fact, most of Junior high school students cannot master in comprehends the recount text is told with identity the characteristics or identity the generic structure of recount text. They only read aloud a recount text and do not understand to identify the characteristic or identify the generic structure of recount text.

Based on the first observation on April 29 $9^{\text {th }}, 2018$ at the eighth grade of SMPN 12 Jambi, the researcher wanted to know about the students' reading comprehension skills to understand the content of recount text, and would like to know the difficulties experienced by students in answering multiple choice questions and the last, the results achieved by the students in learning English.

Based on the description above, the purpose of this research is to find out students difficulties in comprehending a recount text at the eighth grade of SMPN 12 Jambi Academic Year 2018/2019.

\section{METHOD}

The research design in this research proposal is qualitative. According to Bogdan and Taylor (1993) qualitative method is research procedures which produce descriptive data qualitative form of words written or spoken of the people and the observed behavior.

According to Kirk and Miller (1986), qualitative research is a particular tradition in social science that fundamentally depends on human observation both in the region.

From the above description, the researcher concluded that this method of qualitative research is a systematic research methods used to study or examine an object in a natural setting without any manipulation in it and hypothesis testing.

In this research, the setting of the research is in SMPN 12 Jambi. The researcher choose that school because easy to get the data and all of the teachers are friendly. 
The population of this research was only one class, that is VIII 1, this class can representative all of class of the eight grade. There are 32 students. Consists of 16 females and 16 males. Its totals are 32 students.

Based on the explanation of descriptive study with a qualitative approach, the researcher use two technique: interviews and test. Arikunto (2010) argues dialogue conducted by interviewer to obtain information to obtain information from the respondents. Meanwhile according to Anas (2008) interview is how to collect informative materials carried by oral questioning unnaturally, face to face, and with the direction and goals that have been set. By conducting interviews with the respondents can express freely in responds required by the researcher.

Esterberg (2002) argues interview is a meeting of two persons to exchange information and idea through question responses resulting in communication and joint constructing of meaning about a particular topic. Susan Stainback (1988) argues interviewing provide researcher a means to gain a deeper understanding of how the participant interpret a situation or phenomenon than can be gained through observation alone.

From the above description, the researcher concluded that interview will be applied in this research based on consideration that is important to get the complete information from students and English teacher. There are six students and one teacher.

The test is an instrument or systematic procedure for measuring a sample of behavior, for example, to answer the question how well or high performance a person "who she said is numeric (Gronlund, 1985). Tests are one of measurement, and test" is one way to get the information (competencies, knowledge, skills) of students, information about learners can also be obtained through a variety of ways in addition to the test, for example, by means or nontest depending on what data is needed.

Test could be used when the test was valid and therefore reliable, every teacher, mater the techniques required to calculate the reliable and validity. The lack of a valid test can test is based on the following criteria: whether the test contains materials that conform to the curriculum, material that has been taught by teachers, pupils and teachers handbook and a real mastery of the student has achieved, whether by the parties that are considered senior or master the subtleties of the valid tests found. (Roestiyah, 1986).

This research is also use one kind of the test is achievement test that the test to measure the mastery of learner after studies one material is taken by the teacher. Especially measure the students' mastery of recount text comprehension in reading skills. The question test that is given is multiple choices consist of 10 questions and is provided 20 minutes to do the test.

According to Sugiyono (2012) data analysis in qualitative research is an ongoing activity that of occurs throughout the investigative process rather than after process. In this research, the researcher analyzed data to use collection data, reduction data, display data, verification data.

Data collection on the natural setting, the primary data sources, and data collection techniques more participating observation, interview and documentation. Catherine Marshall, Gretchen B. Rossman said that the fundamental methods relied on by qualitative researchers for information gathering are participation in the setting, direct observation, in depth interviewing, document review.

According to Sugiyono (2012) data reduction is sensitive to the thought process that requires intelligence and insight. For researchers who are new, in performing data reduction can discuss with friends or others who considered that the discussion expert. Through insight researchers will develop, thereby reducing the data that has value discovery and development of significant theoretical.

According to Miles and Humberman (1984) states that the most frequent from display data for qualitative research the data in the past has been narrative text.

$M$ based on explanation above, in the analysis, the researcher reduce the data about the students difficulties in answering multiple choice in recount text. In qualitative research, presentation of data can be done in the form of a short description, chart, relationships between categories, flowchart.

\section{FINDINGS AND DISCUSSIONS \\ Findings}

This chapter presents findings and discussions of how is recount text comprehension at eight grade of SMPN 12 Academic Year 2018/2019. The findings were obtained from the analysis of interview and test, followed by discussion.

\section{a. Interview Result}

Based on the result of the interview with the English teacher at SMPN 12 Kota Jambi, the result clearly show that many students who do not understand English lessons, the level difficulty English words thtat make them difficult to translate Indonesian. Students are very interested in learning English when learning to use media such as pictures, graph, tape recorder, etc. classrooms are noisy sometimes hinder the process of learning but as a teacher she can control the behavior of these students. There are many factors that contribute in learning, such as a classroom atmosphere conducive, every student has a textbook, a good delivery of the subject matter, using a variety of learning methods to avoid monotony, and motivation is crucial given to students so eager to learn. Difficulties of the students themselves happen and depending on how the students respond to any given learning materials may also occur because of a motivation and background of each students, of difficulty itself there are some students who 
will figure out a way how to solve difficulty. Many factors and reasons of each they can make a motivation in learning, before the start of the lesson the teacher field study provides a good motivation to the students so that they are easier to understand the material.

One type of text that is studied recount, recount text usually found in the form of multiple choice questions. Students' difficulties comprehend in the recount text because some students have difficulty in understanding the content of the text, and difficult to interpret the English language, which is almost the same answer choices to make confuse students, student reads without understanding the text. The fact that reading failure in Junior High School level is started from their inability to access content at word level. This result correspondent to students answer in interview, the implication is that vocabulary teaching in crucial key. The lack of reading comprehension also happens because of the students limited in constructing main idea from specific details in the text. Understanding pronoun and comprehending generic structure text.

\section{b. Test Result}

Based on the test made by the researcher to complement this research and will explain below: on the results of these tests are a lot of students who answers incorrectly, in particular on the matter of numbers 4, 5, 6 and 7 . In question number 4 ; describes the use of object pronouns, question 5; which asks the contents of the text included in the event, question 6; choose the answer that is not including an explanation of orientation, question7; ask for an explanation of the re-orientation. So, each student was given 10 questions that the students are 32 students, it turns out that the value of the results obtained by the students' results are not much different from the data that researcher get from their English teacher. Thus, of the 32 students who take the test only part that gets good grades and meet the minimum completeness criteria (KKM). Based on the explanation above, it can be concluded that most difficulties to understand text recount, determining the parts of a recount text, and the use of pronouns.

\section{Discussion}

Based on the interview, and test result the researcher founded. It will be describe below: based on the result of the interview with students and English teacher at SMP N 12 Kota Jambi the result clearly show many students who do not understand English lessons, the level of difficulty on any English words that make them have to translate into Indonesian.

Dalyono (2010) states that student difficulties for each individual learning activity can take place is not always fair, sometimes it can quickly grasp what is learned sometimes, but sometimes hard to concentrate, the fact that we often to find each of the students in terms of learning activities, each individual does not have the same. These individual differences that cause differences in learning.

Mulyadi (2010) argues each student has a different ability, and ability have a major impact on learning outcomes achieve. Inability students in a particular subject takes a longer time to master the material, compared to gifted students in subjects other words, the students are given time varied in order to achieve mastery learning materials completely and appropriately can help if they have trouble.

In determining the quality of teaching for pupils. Another factor that affects the success of the learning ability and perseverance as well as the opportunities provided for students to learn the scope of material that determined. There are several factors that make each students having difficulty in English, both from themselves, as well as from environmental factors, difficulties can be overcome will also depend on their own, while following the lesson most of them will be in trouble if the other students who can not to work with good and will disrupt other students concentrate following learning materials, for necessary firmness of teachers of English language study for each student sitting position that aims to get the situation effectively.

All of these factors varied look at a set of students who are in the learning activities, it will be produced a number of students who would have difficulty in achieving learning outcomes is complete with variety of variations, namely: a group of students who have not achieved mastery level, but almost reach it.

The pupils have difficulty in mastering comprehend, difficult parts of the entire material, a person or group of students who have not been able to achieve the level of mastery expected because there is not yet mastered the basic concepts or because already gone through the process of learning.

The type and level of difficulty experienced by students, because it is conceptually not mastered the material studied thoroughly, very low level of mastery of the material, the basic concepts are not mastered, even not only difficult part is not understood, may also parts being and cannot be easily controlled with either. Not infrequent low mastery in just one particular lesson material at a certain period, but could also on a number of subjects, and in some periods.

Maybe students are concerned there is no motivation, no basic knowledge, to the relationship between students and teachers were less harmonious, students are very interested in learning English when learning how touse media such as pictures, graph, tape recorder, etc. classrooms are noisy sometimes hinder the process of learning but as a teacher he can control the behavior of these students. There are so many factors that affect the learning process, such as a classroom environment conducive, every student has a textbook, a good delivery of the subject matter, using a variety of 
learning methods to avoid monotony, and motivation is crucial given to students so eager to learn.

One type of text that is studied recount, according to Suryana (2008) recount text is a text that tell about past event and the general characteristic. Generic structure of recount text consist of orientation tells who was involed, what happened, where the events took place and when it happened. Events tell what happened and it what sequence. Re-orientation consists of optional-closure of events/ending. recount text tells about a special or particular events or incident in the story that is happened by someone. And also has three stages are: orientation that tell who the story about, record of events that retell the events in logical time sequence, and the last is re-orientation that round off the story is being told. Recount text usually found in the form of multiple choice questions. According to Bloom (1981) multiple choice test items are about always consist of two main components, two or more options one more correct answer and the rest are wrong (distractors).

According to Nurgiyantoro Burhan (2010) multiple-choice test is multiple choice and true false representation on any alternative answers and only a precise while others are distractors. Students' difficulties in answering multiple choice questions in the text recount is some students have difficulty in understanding the content of the text, and the text difficult to interpret the English language, which is almost the same answer choices that confuse students, students simply read without understanding the text, not through answering questions. The fact that reading failure in Junior High School level is started from their inability to access content at word level. By definition, Finocchiaro and Bonomo (1973) reading is bringing meaning to get meaning from the printed or written material. Reading comprehension is the ability to obtain information, including the content, understanding the meaning of the passage, and reading is not a passive but an active process, meaning that a reader must actively try to capture the contents of the reading passage should not just accept it.

From test the instruments, on the first test the writer are described the sentences as follow:

1. In the first question, many students had the correctly answered, because the student knew the type of text.

2. In the second question, all of the student were correctly answered the questions. It' was about the function of recount text.

3. In the third question, all of the student are correctly answered, because the students understood the generic structure recount text.

4. In the fourth question, many students had incorrectly answered because the students could not understand difficult object pronouns.
5. In the fifth question, many students had incorrectly answered. The student are not able determine which parts of the text included in the event.

6. In the sixth question, many students had incorrectly answered because students did not understand parts of the text included in orientation.

7. In the seventh question, there were nine students has incorrectly answered because students did not understand parts of the text in the orientation.

8. In the eight question, there were two students had incorrectly answered because the students difficult to determine the title of the text.

9. In the ninth question, there was one student ha incorrectly answered because the student did not understand the tenses were used in the text.

10.In the tenth question, there was one student incorrectly because the student cannot determine the topic sentences in the paragraph.

So, each student was given 10 questions that the students are 32 students, it turns out that value of the result obtained by the students' results are not much different from the data that the researcher get from their English teacher. Thus, of the 32 students who take the test only part that gets good grades and meet the minimum completeness criteria (KKM).

This result it can be concluded that vocabulary teaching is crucial key. The lack of reading comprehension also happens because of the students, limited knowledge in constructing main idea from specific details in the text. Understanding pronouns and comprehend generic structure recount text.

\section{CONCLUSION}

Based on the data analysis, it was found that how recount text comprehension at the eighth grade of SMPN 12 Jambi Academic Year 2018/2019. The researcher found that some students have difficulties in understanding the content of the text. The text difficult to interpret the English language, which is almost the same answer, choices that confuse students, students simply read without understanding the text, not thorough in answering questions.

The students difficult in answering multiple choice questions in recount text are their inability to access the content the text. The result shows us that the most challenging type of task in the work sheet is questions about word meaning. The fact that reading failure in Junior High School level is started from their inability to access content at word level. This result correspondent to students answer in interview, the implication is that vocabulary teaching crucial key. The lack of reading comprehension also happens because of the students, limited knowledge in constructing main idea from specific details in the text. Understanding pronouns and comprehending generic structure text. 


\section{Suggestion}

Based on the data and the discussion in the previous chapter, finally it comes to the following suggestions:

1. The students are recommended to have many exercises in reading, not only reading but also reading comprehension.

2. The students are recommended to practice remember vocabularies.

3. English teacher of Junior high school especially English teacher should guide the students in order to correct students' mistake directly.

4. English teacher of Junior high school especially English teacher should explain more how to comprehend the recount text.

5. English teacher of Junior high school especially English teacher should improve their ability in teaching recount text comprehension.

6. English teacher of Junior high school especially English teacher as motivators should always encourage their students to comprehend the text by giving them much practice to read and comprehend the text.

\section{REFERENCES}

Anas Sudijono. (2008). Pengantar Evaluasi Pendidikan. Jakarta: Raja Grafindo Persada 1996.

Arikunto, S. 2010. Prosedur Penelitian: Suatu Pendekatan Praktik. Jakarata: Penerbit Rineka Cipta.

Benyamin S. Bloom, 1981. All Our Children Learning. Mc Graw-Hill Book Company: New York

Bogdan, Robert dan Steven J Taylor. 1993. Kualitatif Dasar-Dasar Penelitian. Surabaya: Usaha Nasional

Dalyono. 2010. Psikologi Pendidikan Jakarata: Penertbit Rineka Cipta.

Depdiknas. 2004.Undang-Undang SISDIKNAS (Sistem Pendidikan Nasional) 2003 (UU RI No. 20.Th 2003). Jakarta: Sinar Grafika.

Esterberg, Kristin G,2002 ; Qualitative Methods Ins Social Research, Mc Graw Hill, New York

Finocchiaro, Mary dan Michael Bonomo. (1973). The Foreign Language Learner: A Guide for Teacher. New York: Regants Publishing Company, inc

Gronlund, N.E. (1985). Measurement and evaluation in teaching. Fifth Edition. New York: Mc Millan Publishing Co.,Inc.

Kirk, J. \& Miller, M. L., 1986. Reliability and Validity in Qualitative Research, Beverly Hills, CA, Sage Publications.

Miles, M.B \& Huberman A.M. 1984, Analisis Data Kualitatif. Terjemahan oleh Tjetjep Rohendi Rohidi. 1992. Jakarta: Penerbit Universitas Indonesia.

Mulyadi. 2010. Diagnosis Kesulitan Belajar. Yogyakarta: Penerbit Nusa Litera.
Nurgiyantoro, B. 2010. Penilaian Pembelajaran Bahasa. Yogyakarta: Penerbit BFFE. Yogyakarta.

Roestiyah. 1986. Masalah-masalah Ilmu Keguruan. Jakarta: Penerbit PT. Bina Aksara.

Stainback, Susan william Stainback, 1988, Understanding \& Conducting Qualitative Research, Kendall/Hunt Publishing Company, Dubuque, lowa

Sugiyono. 2012. Metode Penelitian Pendidikan. Bandung: Alfabeta.

Suryana, N. 2008. Genre: Reading Comprehension. Jakarta: Penerbit Nobel Edumedia. 